\title{
CAPTURING TECHNOLOGICAL OPPORTUNITY VIA JAPAN'S STAR SCIENTISTS: EVIDENCE FROM JAPANESE FIRMS' BIOTECH PATENTS AND PRODUCTS
}

Lynne G. Zucker Michael R. Darby

Working Paper 6360 
NBER WORKING PAPER SERIES

\title{
CAPTURING TECHNOLOGICAL OPPORTUNITY \\ VIA JAPAN'S STAR SCIENTISTS: EVIDENCE \\ FROM JAPANESE FIRMS' BIOTECH PATENTS \\ AND PRODUCTS
}

Lynne G. Zucker

Michael R. Darby

Working Paper 6360

http://www.nber.org/papers/w6360

\author{
NATIONAL BUREAU OF ECONOMIC RESEARCH \\ 1050 Massachusetts Avenue \\ Cambridge, MA 02138 \\ January 1998
}

This research has been supported by grants from the University of California Systemwide Biotechnology Research and Education Program, the Alfred P. Sloan Foundation through the NBER Research Program on Industrial Technology and Productivity, the National Science Foundation (SES 9012925), and the University of California's Pacific Rim Research Program. We are grateful to Mr. Shozo Hashimoto, Dr. Yoshio Suzuki, Mr. Masayoshi Suzuki, Mr. Takuma Takahashi, and their colleagues at the Nomura Research Institute, Ltd., who arranged most of the interviews for the Japanese fieldwork and provided valuable comments and insights on Japanese policies, institutions, and culture. We also appreciate the very useful comments from Jeff Armstrong, Akio Tagawa, Maximo Torero, and Dr. Kazuo Ueda. Akio Tagawa conducted the initial analysis, co-developed the Japanese firm data set with Yui Suzuki and Benedikt Stefansson, and co-developed the patent data base with Maximo Torero and Richard Powell. Richard Mortimer conducted an extensive sensitivity analysis and calculated the Wooldridge corrections. Gihong Yi was responsible for the analysis of effects of firm ties on scientists' productivity. We are also indebted to a remarkably talented team of post-doctoral fellows Jeff Armstrong, Zhong Deng, Julia Liebeskind, and Yusheng Peng and to Alan Wang, who used his computer science knowledge to make the basic science data base useable. Any opinions expressed are those of the authors and not those of the National Bureau of Economic Research.

(c) 1998 by Lynne G. Zucker and Michael R. Darby. All rights reserved. Short sections of text, not to exceed two paragraphs, may be quoted without explicit permission provided that full credit, including $\odot$ notice, is given to the source. 
Capturing Technological Opportunity via Japan's

Star Scientists: Evidence from Japanese Firms'

Biotech Patents and Products

Lynne G. Zucker and Michael R. Darby

NBER Working Paper No. 6360

January 1998

JEL No. O31

\section{ABSTRACT}

Using detailed data on biotechnology in Japan, we find that identifiable collaborations between particular university star scientists and firms have a large positive impact on firms' research productivity, increasing the average firm's biotech patents by 34 percent, products in development by 27 percent, and products on the market by 8 percent as of 1989-1990. However, there is little evidence of geographically localized knowledge spillovers. In early industry formation, star scientists holding tacit knowledge required to practice recombinant DNA (genetic engineering) were of great economic value, leading to incentives motivating their participation in technology transfer. In Japan, the legal and institutional context implies that firm scientists work in the stars' university laboratories in contrast to America where the stars are more likely to work in the firm's labs. As a result, star collaborations in Japan are less localized around their research universities so that the universities' local economic development impact is lessened. Stars' scientific productivity is increased less during collaborations with firms in Japan as compared to the U.S.

Lynne G. Zucker

Center for International Science, Technology, and Cultural Policy, SPPSR

University of California, Los Angeles

Los Angeles, CA 90095-1551

and NBER

zucker@nicco.sscnet.ucla.edu
Michael R. Darby

Anderson Graduate School of Management University of California, Los Angeles

Los Angeles, CA 90095-1481

and NBER

michael.r.darby@anderson.ucla.edu 


\title{
CAPTURING TECHNOLOGICAL OPPORTUNITY IN JAPAN: EVIDENCE FROM FIRMS' BIOTECH PATENTS AND PRODUCTS
}

\author{
by Lynne G. Zucker and Michael R. Darby
}

\begin{abstract}
R\&D intensity in an industry is largely determined by two key variables technological opportunity and the ability to appropriate returns from new developments.
\end{abstract}

- Klevorick, Levin, Nelson, and Winter (1995, p. 186; their emphasis)

Variations in the degree to which commercially valuable breakthrough knowledge can be captured by persons, firms, industries, and nations provides differential technological opportunities and can translate into sustained competitive advantage in the presence of supporting factors. A stream of recent research on innovation in the U.S. has identified "geographically localized knowledge spillovers" occurring in areas around major universities (Jaffe 1986, 1989). The underlying assumption is that proximity to a major university itself provides technological opportunity; the localization is assumed to be due to the social ties between university and firm employees or by firm employees attending seminars at the university. In sharp contrast, we find that when we measure the actual ties between the university scientists and firms, by using a co-publishing measure that identifies firm scientists who are working at the bench science level with the top university scientists, the effects of other top university scientists working in the same scientific area disappear (Zucker, Darby, and Armstrong 1998).

The central question in this paper is does the same hold true for Japan: When we measure the actual ties between the star university scientists in Japan and firms in Japan, do these ties eliminate the positive, significant effect of untied university scientists? We have already replicated in Japan our U.S. results showing the strong effects of the star scientists making breakthrough bioscience discoveries on the birth of firms adopting biotechnology in Japan, although also documenting the 
dominance of incumbent firms in Japan compared to the dominance of newly formed firms in the U.S. (Darby and Zucker 1996; Zucker, Darby, and Brewer 1997). We now turn to the question of the effects of these scientists on the success of the biotechnology industry in Japan. Here we introduce into our analysis the more commonly used patent measure of innovative output of firms, as well as measures of products in development and on the market that we have used in our earlier U.S. work.

The case of biotechnology is particularly interesting in Japan because Japanese bioscientists are second only to the U.S. in their genetic sequence discoveries, the crucial driving force behind the latest major wave of technology transfer from basic science. The technological opportunity provided by the strong science base meant that Japan's firms had the opportunity to innovate, and our primary question is the role that the top scientists played in this commercialization process. Extensive fieldwork in Japan, and interviews conducted with top bioscientists, top firm officials, and the financial community, provided evidence that there were important ties between the star scientists and firms in Japan. With the many institutional and cultural differences between Japan and the U.S., replicating our earlier results for California would provide strong support for our original conjecture that basic scientific discoveries are commonly appropriated through bench-level scientific collaborations between firm and top university scientists.

Two institutional features of Japan were also explored through our fieldwork. The first is the practice of the top university scientists in Japan of collaborating with firm scientists by bringing these scientists to the university lab, and formally instructing them while informally collaborating with them. The geography of collaboration may well be altered by this practice, since the firm scientists bear the costs of travel or moving. The university and governmental policies underlying this collaboration style will be discussed in more detail below; we use this institutional feature to clarify the differences between the impact of bench level collaboration between star scientists and firms in Japan and the 
U.S. The second institutional feature is keiretsu membership. Specifically, we focus on members of each keiretsu's president's club which often gives firms special entre into funding for new projects. Given the high "burn rate" of capital in biotechnology before products can be marketed, substantial funds must be raised early in the process. Access to funding may provide an initial competitive advantage, but our respondents indicated that the advantage might well be lost through the low risk strategies likely to be adopted within the conservative keiretsu structure. We thus enter president's club membership as a variable in our analysis.

Before turning to the empirical analysis, we briefly discuss how the star scientists are identified in Japan, and then discuss the general conditions under which discoveries can be privatized and thus become "appropriable" by discovering scientists, who can then choose to transfer them to a firm. Some basic comparisons of regional bio-industry variations in Japan and the U.S. are presented in Section II to clarify the common perception that Japan lags significantly behind the U.S. in its commercialization. We then tum in Section III to our main analyses of the market or spillover effects of star scientists on firm success in terms of patents and products in development and on the market. We next examine the effect of commercial ties on the scientific productivity of stars, as measured by number of articles published and their average number of citations. Section $\mathrm{V}$ presents our conclusions on embodied technology transfer and localized spillovers and on how Japanese institutions have attenuated the local economic development impact of Japan's major research universities 


\section{Star Scientists and Natural Excludability of Breakthrough Knowledge}

In a series of papers with our associates (see especially, Zucker and Darby 1996, 1997a, 1997b, Zucker, Darby, and Brewer 1997, Darby and Zucker 1996, and Zucker, Darby, and Armstrong 1998), we have shown that star scientists play a central role in determining where and when firms enter biotechnology and which of them are most successful. We briefly review here how we identify the star scientists and why they play a crucial role in the commercialization of the breakthrough scientific discoveries.

\section{A. Identifying Star Scientists}

The breakthrough discovery by Stanley Cohen and Herbert Boyer of the basic technique for recombinant DNA is the foundation both of a burst of related scientific innovation in the biosciences and of commercial biotechnology (reported in Cohen, Chang, Boyer, and Helling 1973). While other discoveries and techniques have become important in biotechnology, the core technology is the application of genetic engineering based upon the Cohen-Boyer breakthrough of taking a gene from one organism and implanting it in another. ${ }^{1}$

A very important measure of research success is the discovery of nucleotide sequences that determine the characteristics of proteins and other molecules; these sequences and the articles that report them are cataloged in an international scientific data base, GenBank $(1990 ; 1994)$. In this paper, we analyze gene sequence articles up to 1990 by at least one Japanese scientist (except for our data on tacit knowledge, presented in the next section, that includes international articles through 1992). GenBank assigns to each article one or more "primary accession numbers" to identify each genetic sequence. 
Based on these accession numbers, we identified a set of 327 star scientists, 305 with more than 40 genetic sequences through April 1990 and 22 with 20 or more articles (with at least 20 primary accession numbers) to include difficult discoveries that may report fewer sequences per article on average. ${ }^{2}$ Of these stars, 52 published with an affiliation to an institution in Japan at least once (for comparison analyses, we also rely on the 207 stars who published with an affiliation to an institution in the U.S. at least once). Affiliation, including both institution and address (country), are not included in GenBank but were hand coded from 4,061 articles authored by stars. ${ }^{3}$ When we examine the full GenBank just below, we do not have information on the location/affiliation of most authors, only the top performing scientists and their co-authors.

\section{B. Tacit Knowledge Held by the Star Scientists}

Technology transfer by discovering scientists becomes important in determining the success of firms utilizing that technology when a new discovery has both high commercial value and a combination of scarcity and tacitness that defines natural excludability, the degree to which there is a barrier to the flow of the valuable knowledge from the discoverers to other scientists. Those with the most information about breakthrough discoveries are the scientists actually making them, so there is initial scarcity. To the extent that the knowledge is both scarce and tacit, it constitutes intellectual human capital retained by the discovering scientists (Zucker, Darby, and Brewer 1997 and 1994, Data Appendix).

Knowledge provides competitive advantage to the degree that privatization is possible; if none is, then the knowledge is available for all to exploit (and thus there may be few incentives to exploit it). Most, but not all, breakthrough discoveries have a high degree of privatization compared to knowledge produced via "normal science." In the recombinant DNA breakthroughs in bioscience, 
the discovering scientists initially dominated publication; new scientists entered the area of research, but predominantly by working with at least one other scientist who had previously published in the area.

Scarcity of the new knowledge is reflected in classic diffusion, beginning with just a handful of discoverers and growing at a pace that reflects both the value of the knowledge, where high value discoveries will diffuse more widely and rapidly than those with low value, and its tacitness. ${ }^{4}$ When the value is high, as in biotechnology, other scientists are motivated to learn the new knowledge; however when tacitness is high, these other scientists are limited in their ability to learn it depending on the relative scarcity of those who already know it. Scientists desiring to enter the new area of research may need to have hands-on experience at the bench before they are able to enter. Coauthoring, which implies bench level collaboration, provides our measure of tacitness: Degree of tacitness is high when most new authors are publishing with at least one old author defined as those who have published before in GenBank, and low if most new entrants to GenBank can do the research either by him/herself or with all new authors.

Figure 1 illustrates the initial scarcity of the new knowledge, and the overall drop in scarcity as new scientists increasingly publish in GenBank, enlarging the pool over time of scientists who continue to publish on genetic sequence research. As also shown in Figure 1, our tacitness measure declines more slowly than scarcity. In fact, new scientists continue to enter throughout the 1969 through 1992 period predominantly by publishing with old, experienced scientists who have previously published in GenBank, and thus demonstrably know the relevant techniques, with this mode accounting for 81 percent of entry from 1969 through $1992 .{ }^{6}$ Excluding sole-authored articles, which may be dissertations for new authors and review articles by established authors, new authors write exclusively with other new authors 36 percent less frequently than old authors write exclusively 
with other old authors?

To estimate the significance of these differences, in Table 1 we examine the choice by each author to write with all old or new authors or not. We find that being a new author significantly decreases the probability of publishing with all the same type of (here, new) author; old authors are more likely to select working with all old authors as the number of articles they have published previously in GenBank increases. The number of authors per article and the year, both entered as control variables, significantly decrease the probability of publishing with all old or all new authors, compared to publishing with mixed old and new authors.

\section{Regional Variation in Japan and the U.S.}

Because we are interested in exploring geographically localized knowledge spillovers, it was important to define for Japan regions similar to the U.S. Bureau of Economic Analysis's functional economic areas within which commuting is sufficiently feasible to think of knowledge as more easily transmitted locally than to other regions of Japan. Our regional definitions are contained in Table 2. Since most of the action is within such core prefectures as Tokyo, Chiba, and Kanagawa or Kyoto and Osaka or Aichi, we do not believe that other reasonable classifications would lead to materially different results.

In Table 3 we report the distribution of firms located in these regions (by principal research location where this differs from headquarters) and their average performance on five different measures of research productivity used in the empirical analysis: numbers of U.S. biotechnology patents granted, numbers of biotech products in development, numbers of human therapeutics and vaccines biotech products in development, numbers of biotech products on the market, and numbers 
of numbers of human therapeutics and vaccines biotech products on the market. We use data on U.S. patents because of later use of this variable in comparisons with U.S. firms; U.S. patents and Japanese patents have been shown to produce comparable results (Branstetter and Sakakibara 1997, p 23). Of the 368 firms entering biotechnology in Japan 1975-1989, we have product counts (including zeroes but not missing) for 331 . In the U.S., where there are many small, privately-held dedicated new biotech firms, we have comparable data for a much smaller percentage: 342 out of 699 firms as of 1990. The greater density of the Japanese population leads us to compare U.S. states to Japanese regions, but even California (with 8 BEA-defined functional economic areas) has only a little over half the share of firms commanded by Japan's Tokyo area.

Consistent with the industry consensus, American firms are far ahead of their Japanese counterparts, reporting more than twice as many patents and also products on the market, both overall and in the highest-tech/highest-value area of human therapeutics and vaccines. Possibly reflecting differences in our national industry directory sources, the average Japanese firm reports two thirds more products in development than the average U.S. firm overall. However, Japanese firms report human therapeutic and vaccine biotech products in development at a rate one quarter less than in the U.S. While many of our respondents in Japan have expressed concern that their performance persistently lags behind America, we note that Japan has probably done more with its science base than any major European country.

\section{Empirical Analysis}

We report here poisson regressions for three principal measures of success by Japanese firms in using biotechnology: numbers of U.S. biotechnology patents granted, numbers of products in 
development, and numbers of products on the market. The last two measures are also examined where the products in question are restricted to human therapeutics and vaccines to focus on the highest-value/highest-technology applications. Poisson regressions are appropriate as here when dealing with count variables with numerous zero values (Hausman, Hall, and Griliches 1984). All the regressions reported here were estimated using LIMDEP (William Greene 1992, pp. 539-549), with the Wooldridge regression-based correction for the variance-covariance matrix estimates. ${ }^{8}$ The poisson regressions estimate the logarithm of the expected number of firm births; so the signs and significance of coefficients have the usual interpretation.

Sample statistics for these and the other variables used in the empirical analysis are presented in Table 4. The first group of variables are the measures of research productivity to be explained, including both U.S. biotech patent grants with application dates through 1989 and those with grant dates through 1991 (to allow for an average two year lag). ${ }^{9}$ We apply the methods developed in the earlier work focusing on the U.S. to the Japanese case in the following poisson regression models taken from Zucker, Darby, and Armstrong (1998) with the addition of two variables to examine differences between the U.S. and Japanese contexts.

The approach is applied to data for individual firms and based on dividing the articles published by academic (university and independent research institutes) stars in the firm's region into those published with firm coauthors (linked local articles) and all others (untied articles. Proponents of geographically localized knowledge spillovers expect strong positive coefficients on these untied articles while we have concluded in our prior work that localized knowledge effects in this industry have resulted from the tendency of (U.S.) academic stars to work with local firms (of which they are often founders) and the strong effect of star ties on firm's research productivity. As in the U.S. studies, we also include a variable for affiliated stars but in the Japanese case such ties are very rare 
so that variable serves to dummy out the only firm which has affiliated stars.

As noted above, in Japan it is illegal for national university professors (nearly 90 percent of star university scientists) to also work for or receive compensation from firms. Collaborations with firms and technology transfer are legally part of the professors' official duties, but the university does not provide any rewards for moving these items from the bottom of his or her "to-do list." However, many side arrangements provide incentives for faculty-firm collaborations. ${ }^{10}$ Also unlike the U.S., the star scientist does not have to physically do his or her research at the firm's facilities in order for the collaborators to avoid the university's full or co-ownership of any resulting patents. As a result, the collaborations generally involve one of the firm's scientists working in the academic star's university laboratory and serving as liaison to the firm (for example, the star may refer samples to the firm's laboratories for sequencing). Since any firm in Japan can reasonably although not costlessly move one of their scientists to the star's laboratory, it is not surprising that (external) linkages between firms and stars in other regions are relatively much more common in Japan than in the U.S. We alternatively add a count of external linked articles as a separate variable in the regression or combine local and external linked articles in a single variable. In Table 4 we report sample statistics for cumulative values up to 1989 of the five different measures of stars' research output as viewed by the firm.

The one other alteration to the Zucker, Darby, and Armstrong (1998) set-up is addition of a categorical variable indicating whether or not the firm is represented in a keiretsu presidents' club. Advocates of keiretsus would expect such membership to confer deep pockets and long horizons leading to greater research productivity. Some scientists in Japan have indicated that keiretsus are characterized by older, more conservative chief executives who are less likely to adequately commit company resources to modem biotechnology. This is the first item listed as other firm characteristics 
in Table 4.

There are only three other variables appearing in the regressions: (a) a categorical variable indicating whether the company is a new biotechnology firm (only $8.3 \%$ of the Japanese firms compared to three quarters of American firms using biotechnology) or a prior incumbent firm, (b) experience measured as years elapsed since entry in biotechnology, and (c) a categorical variable indicating whether or not the firm actually applies the recombinant DNA technology.

\section{A. Patents Granted}

Table 5 reports estimates of the process determining U.S. biotechnology patents granted to Japanese firms by application dates 1975-1989 (roughly corresponding to grant dates of 1977-1991). For these regressions only the firms active in biotechnology in any given year are entered and the data on star articles are cumulated to that year. We ran corresponding regressions for patents dated by grant dates with essentially identical results. ${ }^{11}$

Consider first model a in Table 5. Collaborations with external stars appear to be very productive in generating patents for the firm. Affiliated stars have a significantly negative coefficient, but for Japan this reflects the comparatively less successful experience of a single firm with affiliated stars compared to what would otherwise be predicted. (Comparison with model b suggests that keiretsu presidents' club membership has a negative impact on predicted patenting success and its inclusion reduces the estimated coefficient of affiliated stars; ${ }^{12}$ since only one firm is involved we generally will not further dwell on the affiliated variable.) Not surprisingly, years of experience and the use of the recombinant DNA technology are significant positive factors in generating patents. Interestingly, incumbent firms in Japan appear to have a significant advantage over entrants in Japan in generating patents. Untied local stars have a tiny negative coefficient in all the models in Table 
5 (which is statistically significant in one case), contrary to the predictions of advocates of geographically localized knowledge spillovers. More surprising, given our U.S. results, is the insignificant coefficient on local linked articles. ${ }^{13}$

The weak effect of local star links may simply reflect the fact that in the Japanese context it is not important where the star is located relative to the firm, so we have relatively few local star links which were less productive than average. Models $\mathrm{c}$ and $\mathrm{d}$ replicate models $\mathrm{a}$ and $\mathrm{b}$ on the assumption that both types of links should be pooled in Japan. The $\chi^{2}(1)$ statistics reported at the bottom of the $c$ and $d$ columns indicate that we can reject that hypothesis for these regressions at the 1 percent confidence level. There is a socio-economic explanation for why external links would be more productive than local links in the Japanese context where greater distance does not entail lesser involvement of the star in the collaboration: Since the firm's costs in sending its scientist to work in the star's laboratory will generally be higher when the star is external to the region, the expected payoff to the firm should be higher for external than local collaborations with stars. (See Zucker, Darby, Brewer, and Peng 1996 for more general evidence of this proposition for scientific collaborations.) Thus greater impact of external than local links can be viewed as strongly confirming the importance of embodied technology transfer from particular top academic scientists to particular firms in response to incentives to collaborate and disconfirming the hypothesis of localized knowledge spillovers.

We suspect that such a strong conclusion is over-reaching and prefer an alternative, statistical explanation for the weaker local-linked effects estimated here: The counts of local and external links are highly correlated across firms, so it is difficult to obtain reliable estimates of the two coefficients separately. The case for this explanation is buttressed by the fact that for one of the six dependent variables in Tables 5-10 local links have a significant positive effect while external links do not and 
for nearly all the other dependent variables we cannot reject the hypothesis of equal coefficients on the two types of links.

Instead of treating each year for each firm as a different observation, in the cross-section analysis reported in Table 6 we treat each firm as a single observation. For the 309 firms which had entered biotechnology by 1986, we cumulate the various star articles up to 1986 to predict the number of U.S. biotechnology patents granted with application dates from 1986 through 1991. The results are rather similar to those obtained by the panel method except: (a) articles by untied stars have a tiny and insignificant positive effect, (b) the negative coefficient on new biotech firms (versus incumbents) are not significant, and (c) whether we can reject pooling the local and external links depends on whether or not the keiretsu presidents' club membership is included in the regression.

Taken together, the robust findings from Tables 5 and 6 are that linked stars (perhaps especially those from other regions), years of experience in biotechnology, use of recombinant DNA technology, and not belonging to a keiretsu presidents' club all increase research productivity measured by patents granted while there is no indication of any geographically localized knowledge spillovers. Since patents may have some problems as an indicator of research productivity (Griliches 1990), we turn to other indicators more directly related to using biotechnology to create new products.

\section{B. Products in Development}

In Zucker, Darby, and Armstrong (1998) we argued that products in development were a good indicator of research productivity, since reaching the stage of clinical trials meant that the product had already passed substantial milestones. In Japan, however, biotechnology is not used so overwhelmingly in the pharmaceutical industry: in Table 3 we saw that human therapeutics and 
vaccines account for less than one third of the products in development in Japan compared to two thirds in the U.S. This means that some reported products in development may both be at a somewhat earlier stage of development, of lesser technical difficulty, and of rather different magnitudes in terms of value to the firm than those we considered earlier. Accordingly we also consider an alternative measure counting only human therapeutic and vaccine biotech products in development. Both counts were based on listings in Nikkei Biotechnology's Biotechnology Guide Japan, 1990-1991 (see Data Appendix for details).

Table 7 reports the results for counts of all biotech products in development as of 1990 . Both linked local and external stars have large, significant impacts on the numbers of products in development. Again the impact of an article with an external star is larger than one with a local star in terms of the point estimates, but here both are statistically significant and we cannot reject the hypothesis that the impacts are equal. As with patents, the firm with the affiliated stars underperforms. Here there are significant but very small coefficients on articles by local stars not tied to the firm, consistent with geographically localized knowledge spillovers, some unmeasured linkages, or both. Experience and use of recombinant DNA technology is again significantly positive, and the effect of being an entrant is significantly negative (as in Table 5 but not 6). Unlike the case for patents, membership in a keiretsu presidents' club is significantly positive, suggesting that these firms may be more successful at developing products despite relatively fewer patents.

Table 8 reports the results for counts of only human therapeutic and vaccine biotech products in development as of 1990 . For these higher value, higher tech products the results are very similar to those for all products except that the impact of linked stars is even stronger, there is no evidence of geographically localized knowledge spillovers or unmeasured linkages, and whether an entrant or incumbent and years of experience are not significant. Taken together, the robust findings from 
Tables 7 and 8 are that linked stars, use of recombinant DNA technology, and membership a keiretsu presidents' club increase research productivity measured by products in development while there is only little or no indication of any geographically localized knowledge spillovers.

\section{Products on the Market}

Our final measures of research productivity are counts of biotech products on the market (both overall and limited only to human therapeutic and vaccine biotech products) as of 1990 . This has both the advantage of not including products that may never make it to market and the disadvantage of being more heavily weighted by lower value products which are faster to the market than pharmaceutical and other products involving more complex development and testing.

Table 9 reports the results for all products on the market. Again, linked external star articles, years of experience, and use of recombinant DNA technology are significant and positive. In models $a$ and $b$, local star links appear to have a significant negative.and affiliated stars (for the first time) a significant positive effect, but we see in models $c$ and $d$ that we cannot reject pooling local and external links in which case the overall effect of links is significantly positive and the effect of affiliated stars is insignificant. Thus it appears that results in models $\mathrm{a}$ and $\mathrm{b}$ reflect the fact that the firm with affiliated stars reports relatively more (low value?) products on the market in comparison to other firms with local links. Note that neither membership in a keiretsu presidents' club nor entrant/incumbent status has a significant effect. So - as in Zucker, Darby, and Armstrong (1998) -the results are similar to the other measures of research success, but with generally less precise estimates and less explanatory power (as judged by the increase in the log-likelihood).

There were very few human therapeutics and vaccines on the market in Japan by 1990 and some of those represented licensing of products developed abroad, so the poisson regressions in 
Table 10 have comparatively little explanatory power and inferences may be fragile. ${ }^{14}$ As usual, the use of recombinant DNA technology and years of experience generally had a significant effect on the number of these products on the market. Like the patent regressions, membership in a keiretsu presidents' club had a significant negative effect on the number of human drugs on the market. This was the only one of our six success measures for which entrant status has a significantly positive effect. The influence of star scientists on this success measure is difficult to interpret.

The regressions in models $\mathrm{a}$ and $\mathrm{b}$ indicate that articles by local linked stars and untied local stars had a significant positive effect while external links were insignificantly negative. In models c and d, we cannot reject pooling local and external links but end up with a point value for total links which is no longer statistically significant (although an order of magnitude larger than the significant coefficient on untied articles). We suspect that, as with the other five measures of success, star links have a large positive effect on bringing human therapeutics and vaccines to market, but that we observed the process too early in this case to detect it reliably.

Taken together, the products on the market variables give ambiguous results. The overall definition is consistent with significant effects from linked stars and no geographically localized effects while the subset for human therapeutics and vaccines finds evidence of geographically localized effects and little or no statistically significant effects of linked stars.

\section{Quantifying the Effects of Linked Articles by Star Scientists}

It is useful to calculate the predicted effects on firm success due to links to star scientists. Table 11 does this for the regressions (model d) in Tables 6, 7, and 9 which combine the local and external links and include the keiretsu presidents' club membership variable. The first column in the Table gives the number of biotech patents, products in development, and products on the market 
predicted by these regression for a firm with no links but otherwise average values of the other variables. The second and third columns give the corresponding predictions if the firm had 2 or 5 linked articles, respectively. (The predicted effect is nonlinear, increasing in the number of links.) The differences are substantial: An otherwise average firm with 2 linked articles could expect to have 77 percent more patents during 1986-1989, and, as of 1990, 60 percent more products in development, and 18 percent more products on the market. For 5 linked articles, the corresponding percentage increases are 317,223 , and 50 . The estimated increase for products in development are on the same order of magnitude as Zucker, Darby, and Armstong (1998) report for California biotech firms while those for products on the market are considerably less than estimated for California. This latter difference may well reflect the long period of product development prior to marketing and the substantial lead of California over Japan (and the rest of the world).

The fourth column of Table 11 calculates the effect of linked stars another way. The actual number of biotech patents over 1986-1989 is estimated to be 34 percent higher than would have been the case with no linkages of star scientists to firms. Similarly, these linkages are estimated to have increased Japan's products in development by 27 percent and on the market by 8 percent.

These numbers illustrate the central role of linkages to star scientists in determining success in commercial applications of biotechnology, both from the point of view of the individual firm and the country as a whole. They illustrate the very real importance of reforms under consideration and underway in Japan to try to increase funding for academic basic research, focus it on the more successful investigators, and break down the legal and institutional barriers to scientists becoming directly involved in commercialization of their discoveries. 


\section{Firm Ties and the Scientific Productivity of Star Scientists}

One of the most surprising results of our examination of commercial ties of U.S. star scientists is the strong positive correlation between the research productivity of the scientists and the extent of their involvement with firms. In Table 12, we report comparable measures of Japanese and American stars' average annual citations to genetic-sequence-discovery articles according to the nature of their commercial ties. In the U.S., there is a clear progression in which the average rate of citation goes up with the extent of commercial involvement, based on field work which suggests that stars linked to local firms in the U.S. are more involved (often as owners) than are stars linked to firm outside the local region. In Japan, the two affiliated stars have below average scientific productivity (as measured by citations) just as their firm has less research success, but otherwise a moderated version of the same pattern occurs in Japan as in America.

The smaller differences between linked and untied citation rates in Japan may be because some Japanese stars who would be tied to firms in the U.S. do not find it worth their while with an incumbent firm and there are many fewer new biotechnology firms or opportunities to start one's own firm on the side. However, we also believe that there is a much weaker direct effect of working with a firm on the scientists' productivity in Japan than in the U.S. where much greater support for the scientist's work can be extracted from firms (or from outside investors in one's own firm): In Japan, the number of articles per year published by both locally and extemally linked stars is significantly higher than untied stars during their period of linkage (but not before or after) However, unlike the U.S. (see Zucker and Darby 1997b), we were unable to find any significant effect on the rate of citations per article to articles written by Japanese stars before, during, or after firm linkage.

Overall, then our examination of the effects of firm ties on Japanese stars' scientific 
productivity indicates that it is in the same direction but considerably weaker in the United States. This is consistent with the more restricted bargaining power of Japanese star scientists who cannot readily access capital markets to start a firm or even obtain large personal payments or research grants from incumbent firms with which they collaborate. As a result, the firms obtain a larger share of the perhaps smaller total payoff to star scientist-firm collaborations.

\section{Conclusions}

Differences in institutional arrangements, laws, and regulations lead to differences in the physical location where academic scientists typically collaborate with firm scientists in Japan and the United States. In Japan, the collaboration typically involves the firm sending one of their best scientists to work in the academic scientist's university laboratory, both learning his or her techniques and serving as liaison to other firm scientists. In the United States, it is more usual for the academic scientist to work at the bench level with firm scientists in the firm's own facilities. This means that there is little difference in the productivity of the process of embodied technology transfer in Japan according to whether the firm is located locally or elsewhere; in the U.S. where the star academic scientists physically travel to the firm, there is a productivity advantage to local collaborations.

These differences are reflected in our analysis of Japanese data. Not only are star scientists' collaborations much less likely to occur locally (compared to the U.S.), links with nonlocal firms are as productive if not more so than local links. External links will appear more productive ex post if they are more costly to the firm (travel and relocation costs for employees) and so require a higher ex ante or expected productivity to justify their initiation. For the most part there is no positive impact on research productivity of firms of local academic stars who are not linked to the firm, but 
statistically significant (although very small) impacts are found in some regressions suggesting the possibility of geographically localized knowledge spillovers and/or academic-star collaborations which are not detected by our co-publishing measures.

Our results do not show that there are no spillovers from academic - or indeed firm research to research in industry. What they do indicate is that such spillovers as do occur appear to be general in nature, equally effecting all firms in Japan (and possibly elsewhere), and not the geographically localized knowledge spillovers emphasized by Jaffe (1989).

In considering the U.S. case, we find strong local economic development effects of great research universities not because the impact of local links is so much stronger than the link of external effects but because a disproportionate amount of academic star-firm links occur locally. In the Japanese case, these local development effects are virtually absent. Consider Table 13 which details the pattern of collaborations which we have detected between academic star scientists and firms. Tokyo, Nagoya (West-Central Honshu), and the Kansai (mostly Kyoto) contribute nearly equally 94 percent of all the linked articles. Tokyo firms account for some 76 percent of the collaborations, keeping all their local stars and attracting 65 percent of the remaining collaborations. Thus, the ability of large Tokyo firms to send scientists to university laboratories throughout the country has sharply reduced the local benefits that we would have anticipated (based on the U.S. results) from the very strong bio-science base in Nagoya and the Kansai. In Darby and Zucker (1996) we did show for Japan that more firms entered biotechnology near where and when star scientists were actively publishing, but that this effect on entry was significantly smaller than in the U.S. Combining a smaller impact on entry with a small to non-existent localized effect on firm success, there is less role for supporting externalities (not examined here) such as agglomeration effects and cross-industry spillovers for the regions around the science base. 
We also found weaker positive effects in Japan on star scientists' scientific productivity during their period of involvement with firms: The large positive effects for affiliated scientists seen in the U.S. were nonexistent for the two affiliated Japanese scientists. For linked scientists there was a significant increase in the number of articles produced per year during their linkage to firms, but no increase in the number of citations per article. We attribute this is an indication that both scientific and pecuniary payoffs to collaboration are lower for Japanese stars who have much more restricted opportunities for exploiting their knowledge commercially than do American academic stars.

Our prior work has shown that for the biotechnology revolution - and, we believe, other scientific-breakthrough-driven technological discontinuities characterized by natural excludability initially there is great value to bench-science involvement in commercialization by the leading scientists who embody the new discoveries. In the U.S. context, this resulted in a distinct pattern of localized effects in which the biotechnology industry arose and succeeded in large part based on proximity to the star scientists. Japan's academic structure leads to a distinctly different pattern, in which access to top academic scientists is no less important to predicting the research productivity of firms entering biotechnology, but in which geographically localized impacts are absent. The fact that the institutional differences lead to such different patterns of economic impact is strong evidence in support of the view that technology transfer in the case of major breakthroughs involves movement of extraordinarily talented people responding to economic and scientific incentives.

\section{Data Appendix}

The data set used here is either drawn directly from or designed to be comparable to that documented in Zucker, Darby, and Brewer $(1994,1997)$ and Zucker, Darby, and Armstrong (1994, 
1998). For additional details, refer to those sources.

\section{A.1. New Biotechnology Enterprises}

The data set for Japanese firms began with a data set we had developed for the U.S. We started by licensing a machine-readable database (North Carolina Biotechnology Center 1992). In line with the U.S. firm data set, we added firms based on listings found in Bioscan. Additional firms from Biotechnology Guide Japan, 1990-91 were included based on a lengthy discussion with Mr. Mitsuru Miyata (Editor-in-Chief) and Ms. Ikuko Uchiyama (Staff Editor) of Nikkei Biotechnology. The discussion enabled us to distinguish those firms actually using the new technologies from those that were listed as a courtesy to subscribers hoping to improve their stock prices. The Nikkei Biotechnology (1994) directory was used to fill in missing data.

The vast majority of the Japanese firms had founding dates prior to their entry into biotechnology, and therefore were classified as incumbents. The remaining 8.2 percent of firms were classified as new biotechnology firms (also termed simply entrants). Apparent response bias led early adopters of biotechnology to report 1975 as the date of entry. We accepted 1975 as the earliest date of entry even though it is doubtful that entry occurred before 1976, given the lag observed in applying the key Cohen-Boyer discovery (Cohen, Chang, Boyer, and Helling 1973) even in the U.S. In four cases, very early entrants gave dates of entry before 1975, apparently referring to earlier technologies; these were constrained to 1975 . This gave us dates of entry for 239 firms. For another 92 firms, no entry dates were available in any of our data sources. Since there was valuable product and patent data associated with these firms, we estimated the entry date of these firms by randomly drawing entry dates from the same distribution as recorded for firms in their prefecture with known entry dates. 


\section{A.2. Measures of Firm Performance}

Our attempt to categorize firm performance began with products in development and products on the market. To be consistent with the categories we used for the United States, Bioscan was used as a starting point. However, consistent data for Japanese firms were not available from this source, so the same categories were carefully applied by Yui Suzuki to the Nikkei Biotechnology (1990) directory. From these categories we have shown results from four important areas: Total products in development, products in development in human therapeutics and vaccines, total products on the market, and products on the market in human therapeutics and vaccines.

In the analyses we use a control variable that specifies whether or not the firm reported using the recombinant-DNA technology that is most closely related to the star scientist measure. This portion of the control variable comes from self-reporting as found in our database from the North Carolina Biotechnology Center (1992). However, Yui Suzuki found upon searching the Nikkei Biotechnology directory that many of the firms which did not report to be using the recombinant DNA technology clearly were doing so, and this information was used to supplement the variable. Information on the number of patents the Japanese firms in our data set had received in the United States were obtained from a CD-ROM data base purchased from the U.S. Department of Commerce Patent and Trademark Office (1993). The patents all came from the Patent Technology Set for Genetic Engineering, Class 935 and Class 435 (subclass 172.3 only). The data contained the dates the patents were granted and the dates for which these successful patents had been applied. In our analyses reported here we use the application date for these patents eventually granted, as this date is much more closely related to the star scientist measures. We use the patent application dates from 1975-1989 for these patents. 


\section{A.3. Defining Stars and Their Firm Affiliation or Linkage}

Previously, Zucker, Darby, and Brewer (1994) have demonstrated the key role in determining where and when firms are found by intellectual capital, namely by observing where and when "star" scientists are actively publishing. Through Genbank (1990), 337 leading "star" researchers were found worldwide on the basis of the number of genetic sequence discoveries and articles up to 1990 for which they were authors. These 337 stars were listed as authors on 4,315 distinct articles in major journals, and these were hand collected and used to identify and locate institutional affiliations for these scientists at the time of these publications. Hand collecting and coding was necessary because databases with this information often failed to identify the specific location for each of the authors. Convention in the field is that the senior author appears as the final author, and databases often specify only the location of the first or corresponding author.

Following Zucker, Darby, and Amstrong (1994, 1998), we have analyzed Japanese firm performance using article level variables; that is, we counted the number of articles written by star scientists and divided them into two distinct categories for our analyses. We call an article "affiliated" to a particular Japanese firm if that firm is listed as the primary affiliation of a star author. Otherwise, they are termed "unaffiliated." Unaffiliated articles are then analyzed with respect to each Japanese firm as either linked to the firm if the star lists his or her primary affiliation as a university or research institute and one or more of the coauthors list their primary affiliations as the firm. Otherwise, we call the unaffiliated article "untied" to this firm (although it may be tied to another firm). Thus, linked stars are those at universities or research institutes who have specific ties to particular firms as identified by their publishing activities with the firm. For the analyses, each firm is geocoded as being located in one of the nine Japanese functional economic areas. In our analyses, we use the expression 
"local" to mean "in the same region as the firm."

We have five firm-specific article-weighted star variables: a count of the number of articles written by stars working for the specific firm (which we call "affiliated"), the number of star-articles in the region not counted as affiliated but which are linked to the firm (which we call "linked local"), the number of star-articles outside of the region also not affiliated but nevertheless linked to the firm (which we call "linked external"), the total number of star-articles either locally linked or externally linked ("linked local \& external"), and finally the number of regional star-articles which are neither affiliated with any firm nor linked to the particular firm (which we call "untied local").

\section{A.4. Keiretsu President's Club Affiliation of Japanese Firms}

Japanese keiretsu are large corporate groupings of related firms. They are typified by crossshareholding and financial relations with a central bank. Such industrial groupings are thought to be of central importance in understanding Japanese industrial organization. There are competing definitions for keiretsu; that is, there is no generally agreed definition or listing of which firms are members of which keiretsu. David Weinstein has generously provided us with the data set constructed for Weinstein and Yishay Yafeh (1995) which contains a member listing for four different definitions of keiretsu. For our analyses, we have chosen the narrowest definition, which is called the Big 6 President's Club, which only includes those Japanese firms in the inner circle of the Big 6 keiretsu firms whose CEOs belong to their group's President's Club. Fifty one of the 331 firms in our data set fall into this category. 


\section{REFERENCES}

Branstetter, Lee, and Mariko Sakakibara, "Japanese Research Consortia: A Microeconometric Analysis of Industrial Policy," National Bureau of Economic Research Working Paper 6066, June 1997.

Cameron, A. Colin, and Pravin K. Trivedi, "Regression-Based Tests for Overdispersion in the Poisson Model," Journal of Econometrics, December 1990, 46: 347-364.

Cohen, Stanley, A. Chang, Herbert Boyer, and R. Helling, "Construction of Biologically Functional Bacterial Plasmids in vitro," Proceedings of the National Academy of Sciences, November 1973, 70(11): 3240-3244.

Darby, Michael R., and Lynne G. Zucker, "Star Scientists, Institutions, and the Entry of Japanese Biotechnology Enterprises," National Bureau of Economic Research Working Paper No. 5795, October 1996.

GenBank, Release 65.0, machine readable data base, Palo Alto, CA: IntelliGentics, Inc., September 1990.

GenBank, Release 81.0, machine readable data base, Bethesda, MD: National Center for Biotechnology Information, February 15, 1994.

Griliches, Zvi, "Patent Statistics as Economic Indicators: A Survey," Journal of Economic Literature, December 1990, 28: 1661-1707.

Hausman, Jerry, Bronwyn H. Hall, and Zvi Griliches. "Econometric Models for Count Data with an Application to the Patents-R\&D Relationship." Econometrica, July 1984, 909-938.

Jaffe, Adam B., “Technological Opportunity and Spillovers of R \& D; Evidence from Firms' Patents, Profits, and Market Value," The American Economic Review, December 1986, 76(5): 9841001. 
Jaffe, Adam B., "Real Effects of Academic Research," American Economic Review, December 1989, 79(5): 957-970.

Klevorick, Alvin K., Richard C. Levin, Richard R. Nelson, and Sidney G. Winter, "On the Sources and Significance of Interindustry Differences in Technological Opportunities," Research Policy, March 1995, 24(2): 185-205.

Nikkei Biotechnology, Biotechnology Guide Japan, 1990-1991, Japan-America Management, Ltd., trans., New York, NY: Stockton Press, 1990. [Translated from the Section on Japanese Companies in '89 Sekai no Baio Kigyo 800 sha (The World's 800 Bioindustry Companies.)] Nikkei Biotechnology, 94/95 sekai no baio kigyo 2000-sha ['94/95 World's 2000 Bioindustry Corporations], Tokyo, Japan: Nikkei Business Publications, 1994.

North Carolina Biotechnology Center, North Carolina Biotechnology Center Japanese Companies Database, machine readable data base, Research Triangle Park, NC: North Carolina Biotechnology Center, April 16, 1992.

Sindelar, Robert D., "Overview/Preview of Current and Future Recombinant DNA-Produced Pharmaceuticals," Drug Topics, April 20, 1992, Supplement, pp. 3-16.

Sindelar, Robert D., "The Pharmacy of the Future," Drug Topics, May 21, 1993, 137(9): 66-84.

U.S. Department of Commerce, Patent and Trademark Office, Patent Technology Set: Genetic Engineering, CD-ROM, machine readable data base, Washington, DC: U.S. Department of Commerce, Office of Information Systems, June 29, 1993.

Weinstein, David E., and Yishay Yafeh, "Japan's Corporate Groups: Collusive or Competitive? An Empirical Investigation of Keiretsu Behavior," Journal of Industrial Economics, December 1995, 43(4): 359-376.

Wooldridge, Jeffrey M., "On the Application of Robust, Regression-Based Diagnostics to Models 
of Conditional Means and Conditional Variances," Journal of Econometrics, January 1991, 47: $5-46$.

Zucker, Lynne G., and Michael R. Darby, "Star Scientists and Institutional Transformation: Patterns of Invention and Innovation in the Formation of the Biotechnology Industry," Proceedings of the National Academy of Sciences, November 12, 1996, 23(23): 12709-12716.

Zucker, Lynne G., and Michael R. Darby, "Present at the Revolution: Transformation of Technical Identity for a Large Incumbent Pharmaceutical Firm after the Biotechnological Breakthrough," Research Policy, 1997 in press. (1997a)

Zucker, Lynne G., and Michael R. Darby, "Academic Scientist-Entrepreneurs and Commercial Success in Biotechnology," in Claude Barfield and Bruce Smith, eds., The Future of Biomedical Research, Washington, DC: American Enterprise Institute for Public Policy Research and The Brookings Institution (copublishers), 1997 in press. (1997b)

Zucker, Lynne G., Michael R. Darby, and Jeff Armstrong, "Intellectual Capital and the Firm: The Technology of Geographically Localized Knowledge Spillovers," National Bureau of Economic Research Working Paper No. 4946, December 1994.

Zucker, Lynne G., Michael R. Darby, and Jeff Armstrong, "Geographically Localized Knowledge: Spillovers or Markets?", Economic Inquiry, January 1998, 36(1): in press.

Zucker, Lynne G.; Darby, Michael R. and Brewer, Marilynn B. "Intellectual Capital and the Birth of U.S. Biotechnology Enterprises." National Bureau of Economic Research Working Paper No. 4653, February 1994.

Zucker, Lynne G., Michael R. Darby, and Marilynn B. Brewer, "Intellectual Human Capital and the Birth of U.S. Biotechnology Enterprises," American Economic Review, September 1997, 
87(4): in press.

Zucker, Lynne G., Michael R. Darby, Marilynn B. Brewer, and Yusheng Peng, "Collaboration Structure and Information Dilemmas in Biotechnology: Organizational Boundaries as Trust Production," in Roderick M. Kramer and Tom R. Tyler, eds., Trust in Organizations, Thousand Oaks, CA: Sage, 1996. [Pp. 90-113] 


\section{FOOTNOTES}

1. The other basic technology is cell fusion (also termed monoclonal antibodies, MABs, or hybridomas) in which lymphocytes are fused with myeloma cells to create rapidly proliferating antibody-producing cells (see Sindelar 1992 and 1993 for more detail).

2. These 327 stars were only $3 / 4$ of one percent of the authors in GenBank but accounted for 17.3 percent of the published articles, almost 22 times as many articles as the average scientist. The Genbank data set, methods of identifying stars, and productivity of the stars are discussed in more detail in the Data Appendix included in Zucker, Darby, and Brewer (1994) and in Zucker and Darby (1996).

3. The Science Citation Index lists up to six of the affiliations listed on the paper but only links the corresponding author to a particular affiliation. Thus, only first- and/or corresponding-author affiliations are available in machine-readable sources and bioscience papers frequently list the head of the lab last. As might be expected, our stars, excluding sole authored articles, were last authors on over 69 percent of the articles, where GenBank articles have on average about 4.8 authors per article.

4. Comparing different scientific breakthroughs to determine the initial starting size of the discoverers, the degree to which learning by doing is involved (coauthoring with "old" scientists as the predominant mode of entry), and the relative rates of "diffusion" is an important next step. For example, a much less tacit process appears to operate in the case of high-temperature superconductors where the know-how was widespread prior to the breakthrough experiment that demonstrated that ceramics incorporating rare earths can work as superconductors at economically interesting temperatures.

5. Exceptions typically include the handful of scientists working in the same very narrow specialized 
area as the discovering scientists. At the extreme, when initial scarcity and tacitness are very high, transmission of the new knowledge will only be to the graduate students and postdocs working in the same lab as the discovering scientists.

6. Reports of publications for 1993 were incomplete in February 1994 so that year has been excluded from the figure and these calculations. In the incomplete reports for 1993, entry with old authors amounted to 83 percent of total entry.

7. Sole-authored articles account for only 6.5 percent of the authorships of new authors and 7.8 percent of the authorships of old authors over this period. Interestingly, new sole authors become more frequent later in the period as the value of the tacit knowledge declined as it became more widespread (see also, Zucker, Darby, Brewer, and Peng 1996).

8. In practice, overdispersion (possibly due to unobserved heterogeneity) is frequently observed in poisson regressions. Given the problems with resort to the negative binomial (A. Colin Cameron and Pravin K. Trivedi 1990), Jeffrey M. Wooldridge (1991) developed a flexible and consistent method for correcting the poisson variance-covariance matrix estimates regardless of the underlying relationship between the mean and variance. We are indebted to Wooldridge and Greene for advice in implementing the procedure in LIMDEP.

9. We believe that the application dating approach is preferable although the results are very similar. 10. The effects on firm success reported below of firm collaborations with these discovering scientists are so high that firms and scientists have developed an informal but effective set of incentives. When firms send scientists to work in the university lab of the professor, the firm may also provide research services and funds for the training of those scientists - including tuition, lab fees, equipment, and lab supplies. Since lifetime employment means that university scientists cannot hire additional personnel, the firm's scientist in the lab and support may significantly augment the work which can be done. Two of the star bioscientists we interviewed in Japan complained that their lab remained significantly 
underfunded compared to comparable stature scientists working in the U.S.; clearly, such scientists receive much lower personal compensation as well. Some firms reported cash payments to collaborating scientists on the same order of magnitude as their university salaries and a number of university scientists become highly compensated board members upon retirement.

Although the university has the right to retain the patent rights for benefit of the national (not university) treasury, patent rights for discoveries in the university are always or nearly so instead assigned to the discovering professor who typically then assigns them to the collaborating firm and receives royalty payments in return. The patent-holder frequently makes contributions to his or her university as well.

While the official policy is to work with more than one firm (to prevent charges of favoritism in allocating state resources), our data reveal few cases of intense overlapping collaborations at the bench level with more than one firm at the same time. The usual strategy is the same as observed with U.S. scientists: Either the scientist works with only one firm or practices "serial monogamy" by ending one bench level collaboration before beginning the next. So the policy does not in fact compromise property rights of specific firms in a scientists' discovery, though our interviews with top corporate officers of the major firms adopting biotechnology in Japan reveal considerable concern over uncertainty that this policy creates.

11. The comparisons are made for regressions which allow for an average two year lag between application and grant date: So, grant dates 1977-1991 were substituted for application dates 19751989 in Table 5 and grant dates 1988-1991 were substituted for application dates 1986-1989 in Table 6.

12. However, note below that membership in the Presidents' club significantly increases the number of products in development. 
13. However, this coefficient is significantly positive and not significantly different from that for external linked star articles in the regressions for products in development discussed below.

14. As noted in the table, a peculiarity of the poisson estimator is that a dummy variable for an observation with a 0 value for the dependent variable is not appropriate because $\log 0$ is undefined (or negative infinity). Since affiliated star articles is essentially a dummy variable for a single firm that had none of these products in 1990, that variable was dropped from Table 10. 
Table 1

Deterninants of Whether an Article's Authors Wi11 Be All o1d or New $(y=1)$

or Will Le uixed O1d and $\operatorname{New}(y=0)$

Logit Analysis

Variables

Constant

Categorical variable $=1$ if author i's is a new author; else 0

Number of articles published by author 1 this year and before

Number of authors on the article

Year of publication for the article

$P^{2}(4)=31,755.6^{* * *}, \quad$ Pseudo $-R^{2}=0.124$
Coefficients

$60.714^{* * *}$

$-0.595^{* * *}$

$0.007^{* * *}$

$-0.435^{* * *}$

$-0.030^{* * *}$
Standard Errors

$$
2.826
$$

0.012

0.001

0.003

0.001

$N=238,926$

Notes: Probability z>x: *<.05, **<.01, ***< $<001$

1. An author is classified as new during the first year the author appears in Genbank (1994) and thereafter is old.

2. There is one observation $i f$ for each article $j$ authored by each author 1 (so an article with 5 authors appears 5 times, once for each author). Only articles with wore than 1 author are included in the estimation.

3. The coefficients are estimates of the elasticity with respect to the variable of the odds ratio that all authors $\mathbf{w 1 1}$ be of the sane type rather than aixed old and new. 
Table 2

Definitions of Functional Economic Areas for Japan

Region Name

Hokkaido

Northern Honshu

Tokyo area

Tokyo ring

West-Central Honshu

Kansai Area

Western Honshu

Shikoku

Kyushu \& Nansei Shoto Islands
Included Prefectures

Hokkaido

Akita, Aomori, Fukushima, Iwate, Miyagi, Niigata, Yamagata

Chiba, Kanagawa, Saitama, Tokyo

Gunma, Ibaraki, Shizuoka, Tochigi, Yamanashi

Aichi, Fukui, Gifu, Ishikawa, Mie

Hyogo, Kyoto, Nara, Osaka, Shiga, Wakayama

Hiroshima, Okayama, Shimane, Tottori, Yamaguchi

Ehime, Kagawa, Kochi, Tokushima

Fukuoka, Kagoshima, Kumamoto, Miyazaki, Nagasaki, Oita, Okinawa, Saga 
Table 3

Regional Variation In Firn Success in Biotechnology

Japan and the U.S. as of 1990-1991

\begin{tabular}{|c|c|c|c|c|c|c|c|}
\hline \multirow[b]{3}{*}{ Region or state } & \multirow{2}{*}{\multicolumn{2}{|c|}{ Firms }} & \multicolumn{5}{|c|}{ Per-Fir Averages } \\
\hline & & & \multirow{2}{*}{$\begin{array}{l}\text { Patent } \\
\text { Totals" }\end{array}$} & \multirow{2}{*}{\multicolumn{2}{|c|}{$\begin{array}{l}\text { Brod, In Dev, } \\
\text { A11 Euman' }\end{array}$}} & \multicolumn{2}{|c|}{ Brod, on Mkte } \\
\hline & Number & XTotal & & & & A11 & Euman' \\
\hline $\begin{array}{l}\text { Tokyo area } \\
\text { Kansai area } \\
\text { Tolyo ring } \\
\text { Test-central Eonshu } \\
\text { Testern Eonshu } \\
\text { Other Japan }\end{array}$ & $\begin{array}{r}158 \\
66 \\
34 \\
29 \\
13 \\
31\end{array}$ & $\begin{array}{r}48 \\
20 \\
10 \\
9 \\
4 \\
9\end{array}$ & $\begin{array}{l}0.71 \\
0.55 \\
0.53 \\
0.00 \\
0.85 \\
0.26\end{array}$ & $\begin{array}{l}3.51 \\
3.59 \\
3.44 \\
2.14 \\
2.92 \\
1.58\end{array}$ & $\begin{array}{l}0.99 \\
1.21 \\
1.24 \\
0.48 \\
0.92 \\
0.68\end{array}$ & $\begin{array}{l}1.53 \\
1.89 \\
1.97 \\
1.59 \\
2.15 \\
0.81\end{array}$ & $\begin{array}{l}0.13 \\
0.45 \\
0.26 \\
0.45 \\
0.23 \\
0.10\end{array}$ \\
\hline Total Japan & 331 & 100 & 0.56 & 3.20 & 0.98 & 1.61 & 0.24 \\
\hline $\begin{array}{l}\text { California } \\
\text { Yassachusetts } \\
\text { New Jersey } \\
\text { New York } \\
\text { Varyland } \\
\text { Other U.S. }\end{array}$ & $\begin{array}{r}96 \\
39 \\
27 \\
24 \\
16 \\
140\end{array}$ & $\begin{array}{r}28 \\
11 \\
8 \\
7 \\
5 \\
41\end{array}$ & $\begin{array}{l}1.72 \\
1.72 \\
1.33 \\
0.58 \\
1.63 \\
0.67\end{array}$ & $\begin{array}{l}1.82 \\
2.59 \\
2.70 \\
1.92 \\
1.13 \\
1.68\end{array}$ & $\begin{array}{l}1.54 \\
0.86 \\
2.15 \\
1.29 \\
0.56 \\
1.09\end{array}$ & $\begin{array}{l}3.97 \\
\mathbf{3 . 7 9} \\
\mathbf{2 . 2 2} \\
\mathbf{4 . 3 3} \\
\mathbf{3 . 5 0} \\
\mathbf{3 . 9 1}\end{array}$ & $\begin{array}{l}0.77 \\
0.87 \\
0.52 \\
0.67 \\
0.38 \\
0.31\end{array}$ \\
\hline Total U.S. & 342 & 100 & 1.18 & 1.89 & 1.26 & 3.79 & 0.55 \\
\hline
\end{tabular}

-U.S. biotechnology patents granted through 1991.

Human therapeutics and vaccines. 
Table 4

Descriptive Statistics for Variables Used in

Analysis of Japanese Firns Using Biotechnology

Variables

Measures of Research Success:

US Biotech Patent Grants to Japanese Firms-Applic. Dates up to 1989

US Biotech Patent Grants to Japanese Firms-Grant Dates up to 1991

US Biotech Patent Grants to Firms Application Dates 1986-1989*

US Biotech Patent Grants to FirmsGrant Dates 1988-1991*

Biotech Products in Bevelopment

Products in Development in Fuman Therapeutics \& Vaccines

Products on the Varket

Products on the Market in Iuman Therapeutics Vaccines

Cunulative Articles as of 1989 by:

Stars Affiliated to the Firm

Stars locally Linked to the Firm

Stars Bxternally Linked to the Firm

Stars Linked to the Firm

Unaffiliated Stars in the Same

Region Untied to the Firm
Mean

S.E.

0.522

2.507

$\mathbf{0}$

34

0.539

2.553

0

35

148.571

Keiretsu President's Club Yenbers
Categorical variable $=1$ if new biotech firm; else 0

Years of Firn Ixperience in Biotechnology as of 1989

Categorical variable $=1$ if the firm uses rDNA; else 0
7.508

3.215

1

0.475

0

0.341
0.220

0.914

1.109

4.107

2.375

0.985

1.607

2.134

0.239

0. 846

0.110

0.006

0.036

0.346

0.057

0.356

0.094

0. 545

83.463

0.154

0.362

0

0.082

0. 274

0

12

12

29

17

15

9

2

5

5

297
1

1

15

1

N=331 (37 out of original 368 firms had uissing data on products on market)

-In these cases, $N=309$. 39 firns fron the original 368 firms in the full firm data set were born after 1986, and an additional 20 firms had a missing value for the rDNA categorical variable. 
Table 5

Poisson Regressions for Number of U.S. Blotechnology Patents

Granted to Japanese Firms by Firm and Year

Application Dates 1975-1989

Variables

Constant

Cunulative star articles:

Linked Local

Linked External

Linked Local External

Affiliated

Untied Local Stars
Coefficients (standard errors)

$\begin{array}{llll}\text { model a } & \text { model b } & \text { model } c & \operatorname{model} d \\ & & & \\ -5.0110^{* * *} & -4.9910^{* * *} & -4.9860^{* * *} & -4.9730^{* * *} \\ (0.1545) & (0.1559) & (0.1575) & (0.1605)\end{array}$

$\begin{array}{cc}0.1108 & 0.0573 \\ (0.0616) & (0.0637)\end{array}$

$\begin{array}{ll}0.4828 * * * & 0.4717^{* * *} \\ (0.0590) & (0.0613)\end{array}$

Affiliated
Untied Local Stars
Other Firm Characteristics:
Keiretsu Presidents' club
Yembership
Categorical variable = 1 if
new biotech firm; else 0
Years of Firm Experience
In Biotechnology in 1986
Categorical variable $=1$ if
firm uses rDNA; else 0
Log-1ikelihood
Log-1ikelihood (coefs. $=0$ )

$x^{2}(1)$ for pooling local and external linked articles

$\begin{array}{llll}-1.1100^{* * *} & -0.8276^{* * *} & -1.1980^{* * *} & -0.9343^{* * *} \\ (0.2422) & (0.2457) & (0.2588) & (0.2649) \\ & & & \\ -0.0012 & -0.0017^{*} & -0.0009 & -0.0013 \\ (0.0007) & (0.0008) & (0.0007) & (0.0007)\end{array}$

$0.2805^{* * *}$

0.2421 ***

(0.0469)

(0.0513) $\begin{array}{lll}-0.5735 * * * & - & -0.5290 * * * \\ (0.1343) & & (0.1404)\end{array}$

$-1.3100^{* *}-1.3390 * * \quad-1.3230 * * \quad-1.3500^{* *}$

$\begin{array}{llll}(0.4790) & (0.4843) & (0.4906) & (0.4985)\end{array}$

$\begin{array}{llll}0.1750 * * * & 0.1868 * * * & 0.1658 * * * & 0.1769 * * * \\ (0.0136) & (0.0146) & (0.0136) & (0.0152)\end{array}$

$2.1380 * * *$

2.2360***

$2.1630 * * *$

(0.1410)

$2.2580 * * *$

(0.1475)

$\begin{array}{llll}\mathbf{- 5 7 7 . 9 8} & \mathbf{- 5 7 3 . 4 4} & \mathbf{- 5 8 1 . 5 4} & \mathbf{- 5 7 7 . 7 3} \\ \mathbf{- 7 2 3 . 5 5} & \mathbf{- 7 2 3 . 5 5} & -\mathbf{7 2 3 . 5 5} & \mathbf{- 7 2 3 . 5 5}\end{array}$

7.11** $8.58 * *$

$N=2567$

Notes: Probability 2>x: $*<.05, * *<.01, * * *<.001$

Standard errors (adjusted by Mooldridge 1991, Procedure 2.1) are in parentheses below coefficients. 
Table 6

Poisson Regressions for Cunulative Number of U.S. Botechnology Patents Granted to Japanese Firns with Application Dates 1986-1989 by Firm

Variables

Constant

Star articles up to 1986 :

Linked Local

Linked External

Linked Local External

Affiliated

Untied Local Stars

Other Firm Characteristics:

Leiretsu Presidents' Club Membership

Categorical variable $=1$ if -0.4312 new biotech firm; else $0 \quad(0.4337)$

Years of Firn Experience in Biotechnology in 1986

$0.2656^{* * *}$

(0.0356)

Categorical variable $=1$ if $1.8750 * * *$

firm uses rDNA; else 0

(0.1879)

$-148.59$ $-210.51$

Log-1ikelihood

Log-likel ihood (coefs.=0)

$x^{2}(1)$ for pooling local and external linked articles
Coefficients (standard errors) model a model b model $c$ model d

$\begin{array}{llll}-4.5830 * * * & -4.6130 * * * & -4.4580^{* * *} & -4.4700 * * * \\ (0.3418) & (0.3338) & (0.3380) & (0.3425)\end{array}$
0.0390
$(0.1743)$
$-0.0654$
(0.1779)

$\begin{array}{cc}0.5153 * * * & 0.5110 * * * \\ (0.0817) & (0.0838)\end{array}$

$\begin{array}{ll}-0.3351 * & -0.0582 \\ (0.1554) & (0.1717)\end{array}$

$0.3301 * * *$

$0.2857^{* * *}$

(0.0637)

(0.0713)

$-0.5777 * * *-0.3902 * * *$

(0.1239) (0.1101)

$\begin{array}{cccc}0.0012 & 0.0008 & 0.0014 & 0.0012 \\ (0.0009) & (0.0009) & (0.0009) & (0.0009)\end{array}$

$-0.5985 * *$

$-0.4818^{*}$

(0.1924)

$(0.2079)$

$\begin{array}{lll}-0.4892 & -0.4225 & -0.4662\end{array}$

$(0.4344)$

$(0.4610)$

(0.4701)

$0.2830 * * *$

$0.2451 * * *$

$0.2565^{* * *}$

(0.0363)

(0.0336)

$(0.0361)$

$1.9870 * * *$

$1.8770 * * *$

$1.9680 * * *$

(0.1994)

(0.2089)

(0.1928)

$-150.16$

$-149.03$

$-210.51$

$-210.51$

$-210.51$

3.14

4.38*

$\mathbf{N}=309$

Notes: Probability $2>x$ : $*<.05, * *<.01, * * *<.001$ Standard errors (adjusted by Wooldridge 1991, Procedure 2.1) are in parentheses below coefficients. 
Table 7

Poisson Regressions for Number of Biotech Products in Development by Japanese Fires as of 1990

Variables

Coefficients (standard errors)

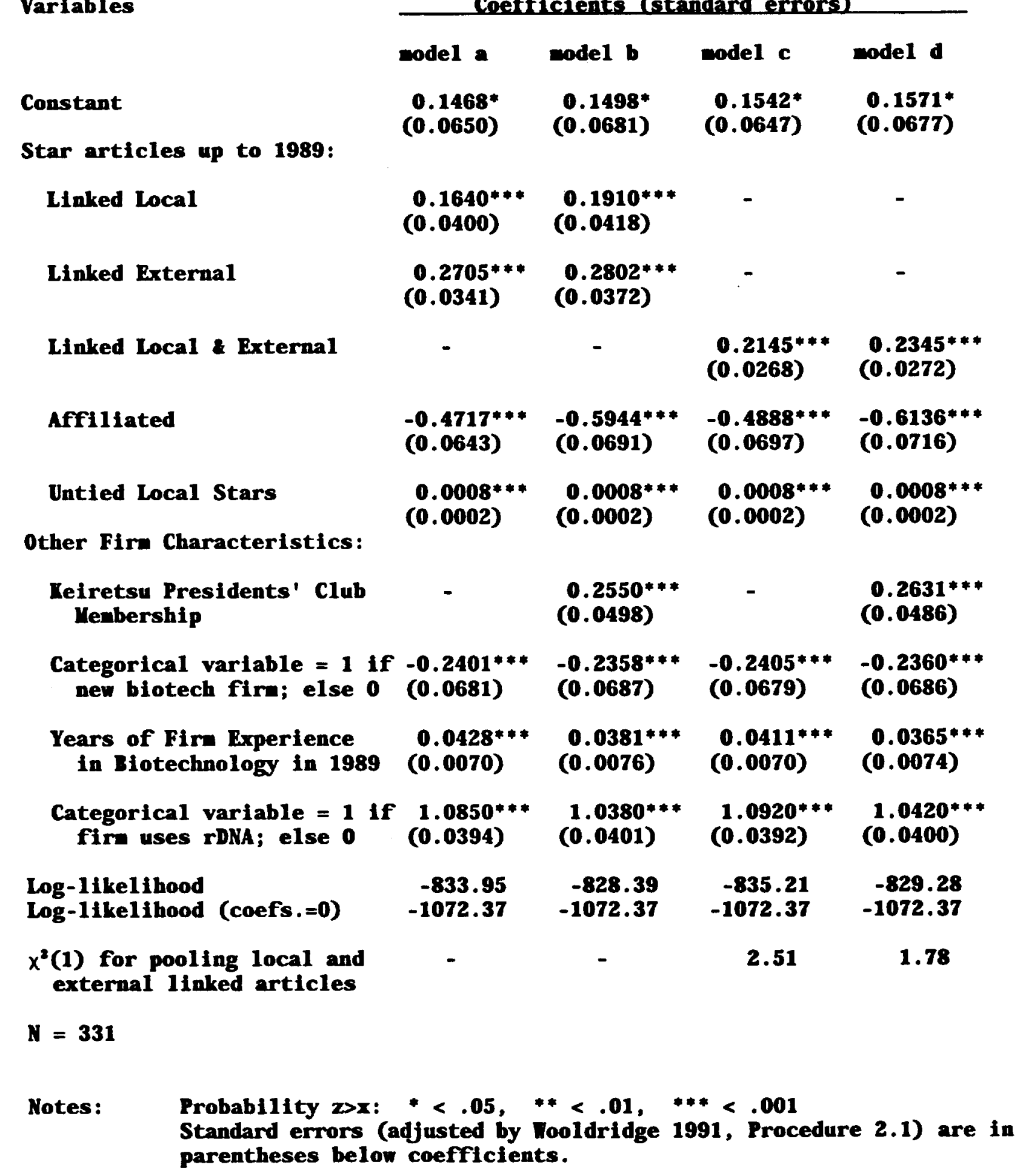

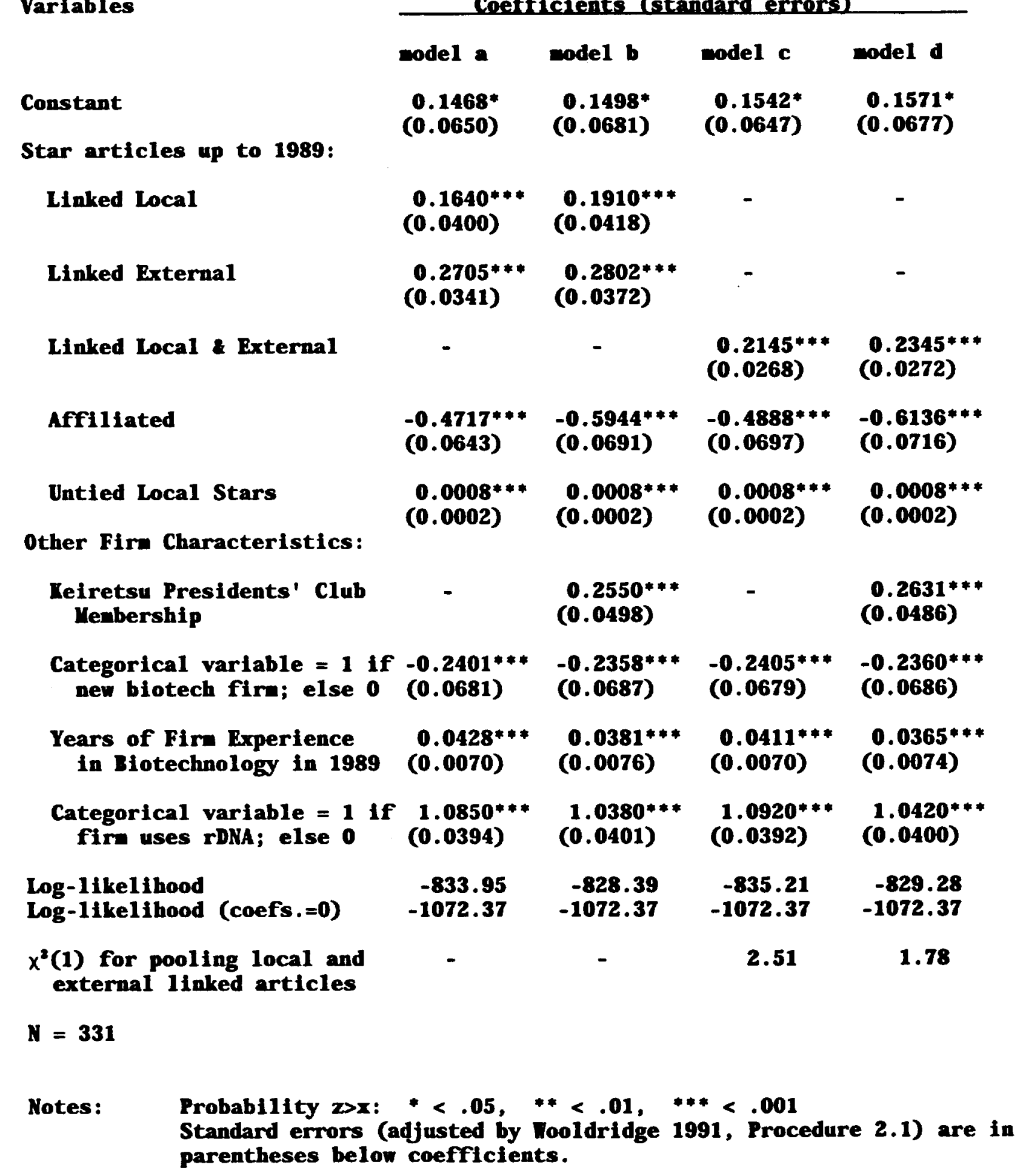


Table 8

Poisson Regressions for Number of Euman Therapeutic Vaccine Biotech Products in Development by Japanese Firms as of 1990

Variables

Constant

Star articles up to 1989 :

Linked Local

Linked External

Linked Local External

$$
\text { Affiliated }
$$

Untied Local Stars

Other Firn Characteristics:
Coefficients (standard ercors)

\begin{tabular}{llll}
\hline nodel a & model b & nodel $c$ & nodel d \\
& & & \\
$-1.4990^{* * *}$ & $-1.4980^{* * *}$ & $-1.4770 * * *$ & $-1.4760 * * *$ \\
$(0.1204)$ & $(0.1244)$ & $(0.1201)$ & $(0.1243)$
\end{tabular}

$0.2917 * * * 0.3098 * * *$

(0.0262)

$(0.0279)$

$$
\begin{array}{cc}
0.4544 * * * & 0.4591 * * * \\
(0.0295) & (0.0322)
\end{array}
$$

$0.3692^{* * *}$

$0.3834 * * *$

(0.0239)

(0.0247)

\begin{tabular}{|c|c|c|c|c|}
\hline $\begin{array}{l}\text { Reiretsu Presidents' Club } \\
\text { Meubership }\end{array}$ & - & $\begin{array}{r}0.1798^{*} \\
(0.0844)\end{array}$ & - & $\begin{array}{l}0.2040^{*} \\
(0.0827)\end{array}$ \\
\hline $\begin{array}{r}\text { Categorical variable }=1 \text { if } \\
\text { new biotech firm; else } 0\end{array}$ & $\begin{array}{l}-0.1148 \\
(0.1730)\end{array}$ & $\begin{array}{l}-0.1156 \\
(0.1799)\end{array}$ & $\begin{array}{l}-0.1176 \\
(0.1734)\end{array}$ & $\begin{array}{l}-0.1183 \\
(0.1810)\end{array}$ \\
\hline $\begin{array}{l}\text { Years of Firm Experience } \\
\text { in Blotechnology in } 1989\end{array}$ & $\begin{array}{c}0.0109 \\
(0.0100)\end{array}$ & $\begin{array}{c}0.0076 \\
(0.0106)\end{array}$ & $\begin{array}{c}0.0056 \\
(0.0099)\end{array}$ & $\begin{array}{c}0.0021 \\
(0.0103)\end{array}$ \\
\hline $\begin{array}{l}\text { Categorical variable }=1 \text { if } \\
\text { firm uses rDNA; else } 0\end{array}$ & $\begin{array}{l}2.0600 * * * \\
(0.0783)\end{array}$ & $\begin{array}{l}2.0290 * * * \\
(0.0803)\end{array}$ & $\begin{array}{l}2.0770^{* * *} \\
(0.0779)\end{array}$ & $\begin{array}{l}2.0400 * * * \\
(0.0802)\end{array}$ \\
\hline $\begin{array}{l}\text { Log-1ikelihood } \\
\text { Log-1ikelihood (coefs. }=0)\end{array}$ & $\begin{array}{l}-475.31 \\
-672.06\end{array}$ & $\begin{array}{l}-474.41 \\
-672.06\end{array}$ & $\begin{array}{l}-476.93 \\
-672.06\end{array}$ & $\begin{array}{l}-475.77 \\
-672.06\end{array}$ \\
\hline $\begin{array}{l}x^{2}(1) \text { for pooling local and } \\
\text { external linked articles }\end{array}$ & - & - & 3.24 & 2.72 \\
\hline
\end{tabular}

$$
\begin{array}{llll}
-0.5883^{* * *} & -0.6722 * * * & -0.6072^{* * *} & -0.7021^{* * *} \\
(0.0373) & (0.0554) & (0.0518) & (0.0640)
\end{array}
$$

$\begin{array}{cccc}0.0004 & -0.0004 & -0.0005 & -0.0005 \\ (0.0003) & (0.0003) & (0.0003) & (0.0003)\end{array}$

Notes: Probability z>x: * $<.05, * *<.01, * * *<.001$

Standard errors (adjusted by Wooldridge 1991, Procedure 2.1) are in parentheses below coefficients. 
Table 9

Poisson Regressions for Number of Biotech Products on the larket by Japanese Firms as of 1990

Variables

Constant
Star articles up to 1989 :

Linked Local

Linked External

Linked Local External

Affiliated

Untied Local Stars

Other Firm Characteristics:

Reiretsu Presidents' Club Membership

Categorical variable $=1$ if -0.1474 new biotech firm; else 0 (0.1034)

Years of Firn Experience in Biotechnology in 1989

Categorical variable $=1$ if firm uses rDNA; else 0

Log-11kelihood

Log-11kel thood (coefs . $=0$ )

$x^{2}(1)$ for pooling local and external linked articles
Coefficlents (standard errors) model a model b model $c$ model d

$\begin{array}{llll}-0.2727^{* *} & -0.2738^{* *} & -0.2622^{* *} & -0.2632^{* *} \\ (0.0980) & (0.0979) & (0.0981) & (0.0981)\end{array}$

$-0.0982^{*}-0.1043 *$

(0.0445) (0.0451)
$0.1746 * * *$
$0.1727 * * *$
(0.0349)
$(0.0347)$

$(0.0981)$ 
Table 10

Poisson Regressions for Number of Buman Therapeutic Vaccine

Biotech Products on the Market by Japanese Firms as of 1990

Variables

Constant

Star articles up to 1989:

Linked Local

Linked External

Linked Local External

Untied Local Stars

Other Firm Characteristics:

Ieiretsu Presidents' Club Membership

Categorical variable $=1$ if $0.4362 *$ new biotech firm; else $0(0.2071)$

Years of Firv Experience in Biotechnology in 1989

$0.0323^{*}$

$(0.0129)$

Categorical variable $=1$ i firm uses rDNA; else 0

$1.5980 * * *$

(0.1242)

$-204.79$

$-233.81$

Log-1ikelihood

Log-1ikel thood (coefs. $=0$ )

$x^{2}(1)$ for pooling local and extermal linked articles
Coefficients (standard errors)

wodel b model $c \quad$ model d

$-3.1100 * * *$

$-3.1180 * * *-3.1160 * * *$

$(0.2303)$

$(0.2310)$

$-0.0381 \quad-0.0534$

(0.0689) (0.0702)
$(0.0005)$
$0.0032^{* * *}$
$0.0032^{* * *}$
$0.0032 * * *$
$(0.0005)$
(0.0005)
(0.0005)

0.0554

0.0355

(0.0373)

$(0.0382)$

$M=330$

Notes:

Probability 2>x: *<.05, **<.01, ***<.001

Standard errors (adjusted by Wooldridge 1991, Procedure 2.1) are in parentheses below coefficients.

Affiliated scientists and the observation for the corresponding firm has been dropped from this analysis. The one observation that has affiliate scientists did not have any human therapeutic or human vaccine products on the market as of 1990 . As a result, this coefficient on this variable would approach negative infinity to fit the poisson model. 
Table 11

Estimated Rffect of Linked Articles on Measures of Success in Bhotechnology

Measure of Success

Cumulative U.S. Biotech

Patents Granted to Japanese

Firus--1986-1989 Applications

Number of Biotech Products

in Development as of 1990

Number of Biotech Products on the Market as of 1990

$\frac{\text { Number of Linked Articles" }}{2}$

0.16

0.29

0.68

8.13

1.27

2.52

4.02

1.75

2.24

1.08

actual average+

1.34

1.48

(2)

\author{
o-1inks value
}

1.34

7


Table 12

Japanese and American Stars' Average Annual Citations by Cowercial Ties

Type of Linkage to Fire

Affiliated

Localc

External

Untiede

A11 stars

\begin{tabular}{cc}
\multicolumn{2}{c}{ Average Lifetine Citations" } \\
\hline Japanese Stars & Anerican Stars \\
77.2 & 323.0
\end{tabular}

149.2

159.3

131.2

109.4

105.8

72.2

118.0

104.4

Notes: A few stars who published in both countries are counted as both Japanese and American stars.

a. The values are the total number of citations in the Science Citation Index for the 3 years 1982, 1987, 1992 for all genetic-sequence discovery articles (up to April 1990) in Cenlank (7) authored or coauthored by each of the stars in the cell divided by 3 (years) tiwes the number of stars in the cell.

b. A11 stars ever publishing a genetic-sequence discovery article and listing an affiliation with a Japanese or American biotechnology firn, respectively.

c. Any other star ever coauthoring with scientists from a biotechnology firm in the same region (defined in Table 2 for Japan, functional economic areas as defined by the Bureau of Econonic Analysis for the v.S.)

d. Any other star ever coauthoring with scientists from a biotechnology firm not located in the sane region (including foreign firms).

e. A11 remaining stars who ever published in Japan or the U.S., respectively. 


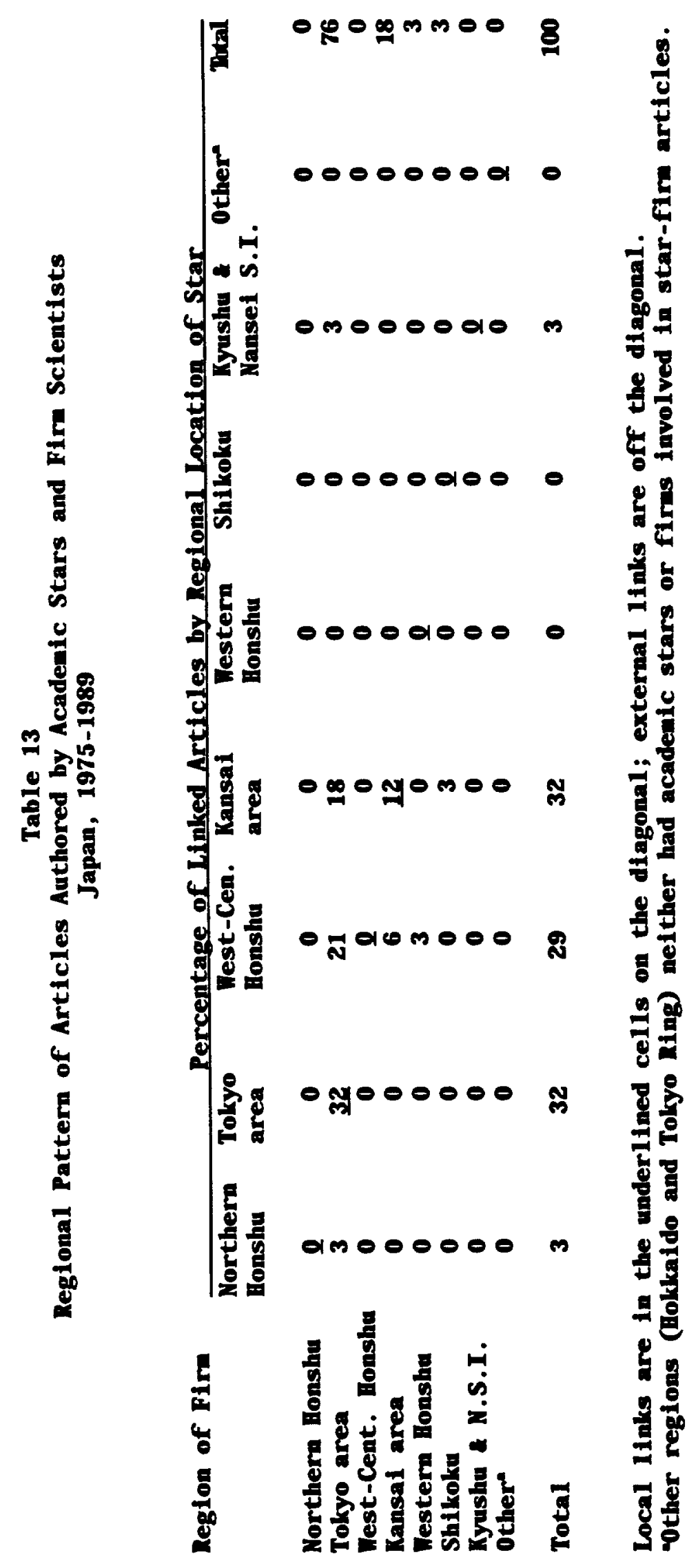




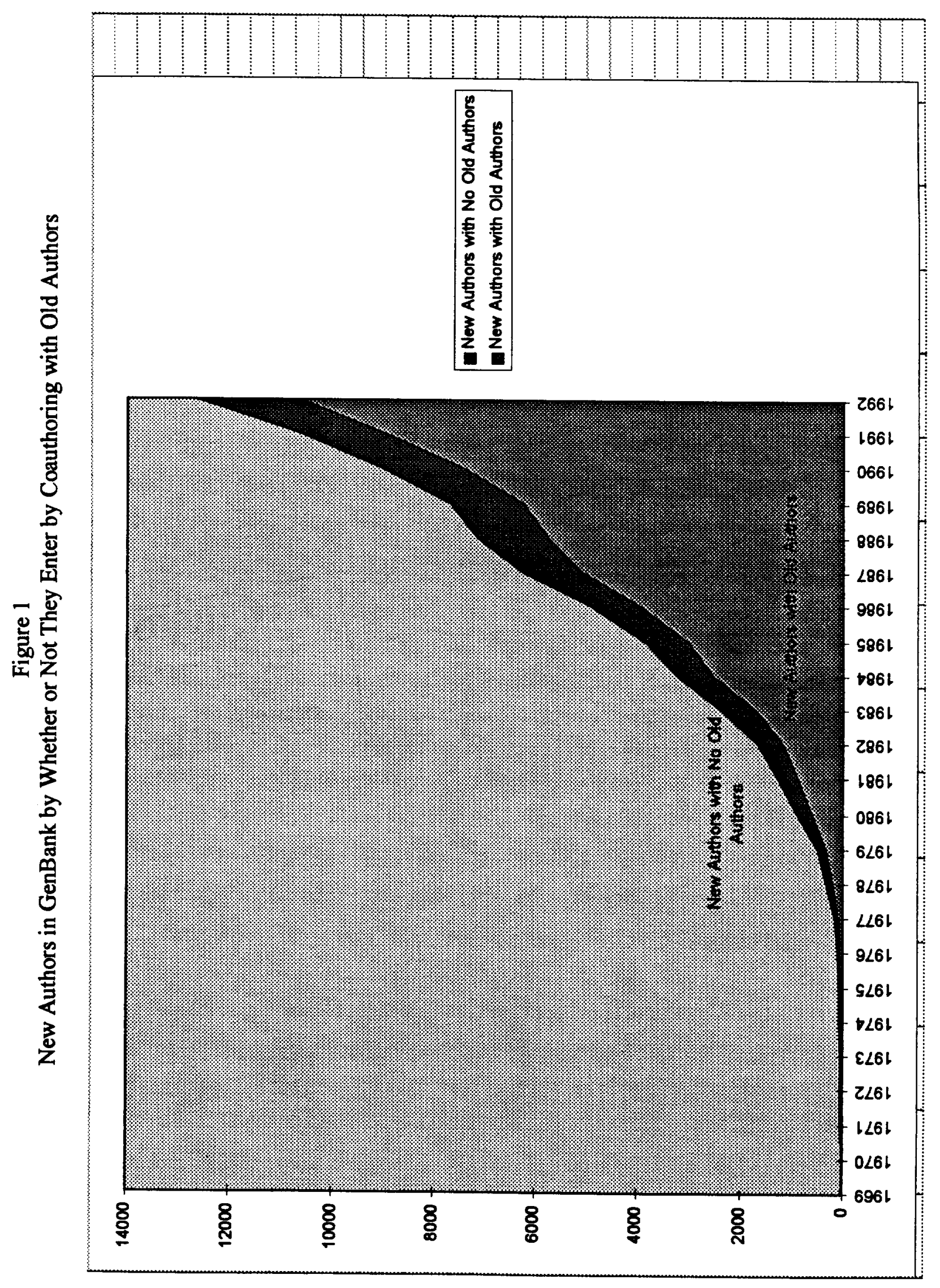

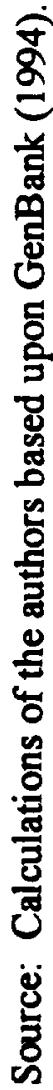

